\title{
A (de)construción identitaria homosexual na conversa. Implicacións sociocul- turais no discurso gay galego
}

Daniel Amarelo Montero ${ }^{1}$

Recibido: 15 de xuño de 2019 / Aceptado: 18 de novembro de 2019

Resumo. No presente traballo, estudaremos os procesos de construción identitaria que se deseñan á volta da sexualidade nun grupo de xoves galegos non heterosexuais, de entre 20 e 30 anos e con distintas orixes socio-xeográficas. Após introducir o estado da cuestión, resumir o percorrido metodolóxico e teórico que nos guiará e presentar o corpus que serve de base empírica, mostramos algúns anacos de conversas reais orais que gravamos para este fin. Por tanto, analízase o corpus oral que recompilamos á luz de cuestións de relevancia para o estudo discursivo da sexualidade contemporánea, partindo da Análise Crítica do Discurso, das teorías da identidade na súa aplicación á lingua e dos Estudos de Xénero e Sexualidade nas súas propostas posidentitarias actuais. En todo momento, temos presentes as particularidades galegas, así como o feito de non contarmos con moita actividade intelectual e académica no noso ámbito á volta do asunto. Finalmente, nesta liña, concluímos con algunhas vías de futuro para a cuestión da linguaxe e as sexualidades non normativas nos seus aspectos socio-discursivos.

Palabras chave: lingua e sexualidade; identidade; Análise Crítica do Discurso; performatividade; LGBTIQ+.

\section{[es] La (de)construcción identitaria homosexual en la conversación. Implicaciones socioculturales en el discurso gay gallego}

Resumen. En el presente trabajo, estudiaremos los procesos de construcción de identidad que se diseñan acerca de la sexualidad en un grupo de jóvenes gallegos no heterosexuales, de entre 20 y 30 años y con distintas procedencias socio-geográficas. Después de introducir el estado de la cuestión, resumir el recorrido metodológico y teórico que nos orientará y presentar el corpus que sirve de base empírica, mostramos algunos fragmentos de conversaciones reales orales que grabamos para este fin. Por tanto, analizamos el corpus oral que recopilamos en función de cuestiones relevantes para el estudio discursivo de la sexualidad contemporánea, partiendo del Análisis Crítico del Discurso, de las teorías de la identidad en su aplicación a la lengua y de los Estudios de Género y Sexualidad en sus proposiciones postidentitarias actuales. En todo momento, tenemos presentes las particularidades gallegas, así como el hecho de que no contamos con mucha actividad intelectual y académica en nuestro ámbito en torno a este asunto. Finalmente, en esta dirección, concluimos con algunas vías de futuro para la cuestión del lenguaje y las sexualidades no normativas en sus aspectos socio-discursivos.

Palabras clave: lengua y sexualidad; identidad; Análisis Crítico del Discurso; performatividad; LGBTIQ+.

\section{[en] (De)construction of Homosexual Identity in Conversation. Socio-cultural Im- plications in Galician Gay Discourse}

\begin{abstract}
In this paper, we will study the processes by which identity is constructed around sexuality in a group of nonheterosexual Galicians aged between 20 and 30 and from a variety of socio-geographic backgrounds. After introducing the topic, outlining the methodological and theoretical principles which guide our work, and summarising the corpus which will serve as our empirical basis, we will present some extracts of the real spoken conversations that we recorded for this purpose. We aim, therefore, to analyse the spoken corpus which we have collected to form a discursive study on contemporary sexuality, starting from Critical Discourse Analysis, the application of identity theories to language, and the contemporary propositions of post-identity from Gender and Sexuality Studies. The particularities of Galiza form a backdrop to our analysis, in particular the lack of intellectual and academic thought surrounding this issue. Finally, with this in mind, we suggest some future paths of study on the topic of language and socio-discursive aspects of non-normative sexualities.
\end{abstract}

1 Instituto da Lingua Galega, Universidade de Santiago de Compostela.

Correo-e: daniel.amarelo.montero@usc.es 
Keywords: Language and Sexuality; Identity; Critical Discourse Analysis; Performativity; LGBTIQ+ .

Sumario. 1. Introdución. 2. As relacións entre lingua, identidade e sexualidade: cuestións teóricas. 2.1. Deconstruíndo e rehumanizando: a ACD. 2.2. O papel (lingüístico) da identidade. 2.2.1. A identidade na interacción: unha proposta de estudo sociocultural. 2.3. A sexualidade contemporánea e os estudos discursivos: algúns gritos de emerxencia. 3. Metodoloxía e traballo de campo. 4. Análise do corpus. 4.1. Etiquetas e termos identitarios. 4.2. O outing como fenómeno discursivo: narrativas persoais sobre a "saída do armario". 4.3. A mercantilización das identidades e a alternativa agrocuir. 5. Conclusións. 6 . Referencias bibliográficas.

Como citar: Amarelo Montero, D. (2019): “A (de)construción identitaria homosexual na conversa. Implicacións socioculturais no discurso gay galego", en Madrygal. Revista de Estudios Gallegos 22, pp. 31-49.

\section{Introdución}

Desde hai algunhas décadas, os procesos de globalización propios da modernidade tardía (Santos 2005, Souza 2010, Hall 2011) provocaron que as relacións tecidas entre os diferentes axentes sociais, e destes coas súas identidades, sufrisen algunhas mudanzas sen precedentes. As políticas identitarias das décadas de 1970 e 80, especialmente en contextos anglófonos, deron paso a concepcións posidentitarias dos suxeitos falantes, nun xiro performativo en que a repetición socializada determina aquilo con que eles/as se constrúen na sociedade capitalista posindustrial. Tamén nos estudos lingüísticos, a "nostalxia sociolingüística" (Bucholtz 2003) das pasadas décadas reduciu a súa presenza en favor de novas subxectividades marxinadas social, política e economicamente, e agora lexitimadas como suxeitos de estudo. Este novo enfoque na pescuda do papel social da linguaxe posibilitou o propio xurdimento do campo de estudos de linguaxe e sexualidade, abandonando modelos clásicos de estudos de lingua e xénero que se limitaban a asignar a determinados trazos lingüísticos explicacións culturais binarias ou deterministas. Así, hoxe falamos de procesos dinámicos de (de)construción de identidades sexuais na interacción e xa non de características preasignadas a tales, incontestábeis, categorías sexoxenéricas.
Porén, na Galiza o traballo sociolingüístico, en sentido lato, camiñou por vías cuantitativas máis do que cualitativas e macrosociolingüísticas máis do que microsociolingüísticas e microsociolóxicas. Ademais, os estudos de xénero e sexualidade, de que este traballo bebe, non están a motivar investigacións lingüísticas de relevo ${ }^{2}$ se os compararmos coas nutridas consecuencias que si están a provocar nos Estudos Culturais e Literarios no territorio galego. Foi por iso que realizamos unha humilde pesquisa desde a Facultade de Filoloxía da USC, cuxo obxectivo era estudar os procesos discursivos de construción identitaria en rapaces galegofalantes de entre vinte e trinta anos. Con esa base, e desde o modelo do construcionismo social e da performatividade, propuxémonos estudar as relacións entre os usos lingüísticos e a identidade sexual na Galiza contemporánea, entendendo por identidade sexual o conxunto de marcos sociais mediante os que individuos e grupos son categorizados por si mesmos e por outros en termos da súa orientación sexual, das súas opinións e crenzas sobre a sexualidade e/ou das súas prácticas sexuais (Queen 2017: 204).

Neste sentido, resulta imprescindíbel contar con materiais reais de fala para unha correcta análise da construción identitaria, reparando nas conversas, ese lugar espontáneo onde os distintos interlocutores se presentan, negocian, contrastan opinións, constitúen ideoloxías etc. É na lingua oral onde florecen, espontaneamente, toda unha serie de trazos e estratexias que modulan as categorías operativas para os falantes e a relación que entre eles trazan. Isto permite problematizar as concepcións sobre a sexualidade, sexa o que isto for. A Análise Crítica do Discurso (ACD) como programa de pesquisa facilita o traballo de desvendamento das ideoloxías que funcionan a este respecto na interacción oral, explicando as microinteraccións diarias na súa realización de macroestruturas sociais e ideolóxicas, quer nun sentido reprodutivo quer nun sentido contestativo.

Por tanto, fuximos de concepcións esencialistas sobre as categorías sexuais e lingüísticas para estudar de xeito dinámico e interdisciplinar os procesos de construción de identidades no discurso falado en galego. Para iso, non

2 É perceptíbel unha mudanza de rumo nestes últimos anos, sobre todo na Sociolingüística Interaccional, con algúns exemplos considerábeis como os estudos de Basanta 2014, 2017, que aprofundan na cuestión de xénero e sexualidade na lingua galega. 
serán propostas caracterizacións da chamada "fala dos homosexuais" nin se sosterá a idea dunha "comunidade lingüística homosexual" (Leap 1996; Valcárcel 1998: 38) senón que se estudarán interaccións concretas en que a identificación moldea a conversa sobre a sexualidade. Dada a ausencia deste tipo de achegas, colócase un chanzo inicial para futuros traballos sobre o galego que posibiliten que o traballo etnográfico e lingüístico sobre as sexualidades non hexemónicas saian dos territorios anglófonos e das capitais máis europe(izad)as. Neses territorios, a introdución da sexualidade no programa investigador revolucionou, de facto, os propios campos da Análise do Discurso e dos Estudos de Xénero ${ }^{3}$.

\section{As relacións entre lingua, identidade e se- xualidade: cuestións teóricas}

\subsection{Deconstruíndo e rehumanizando: a ACD}

Na década de 90, Pierre Bourdieu advertíanos de procurar o poder das palabras dentro das propias palabras, alí onde precisamente nunca sería encontrado (1994: 108). O pensamento deste sociólogo francés golpeou o cerne das concepcións estruturalistas sobre a lingua e a cultura nunha defensa teórica de aproximación entre as ciencias da linguaxe e a ciencia dos usos sociais da lingua. $\mathrm{O}$ deseño teórico do concepto de poder simbólico e a súa aplicabilidade á linguaxe supuxeron un antes e un despois á hora de entender as trocas comunicativas no seo do "mercado lingüístico", onde os diferentes axentes dun campo, con cadanseu habitus, constrúen a diferenza lingüística en termos de lexitimidade. É na obra Language and Symbolic Power, en que revisa a teoría da performatividade de Austin (1962), onde estabelecen as condicións institucionais en que ten lugar a eficacia simbólica dos discursos:

only in so far as the person subjected to it recognizes the person who exercises it as authorized to do so, or, what amounts to the same thing, only in so far as he fails to realize that, in submitting to it, he himself has contributed, through his recognition, to its establishment. (Bourdieu 1994:116)

Para alén da Socioloxía, o que hoxe entendemos por Análise (Crítica) do Discurso debe a súa xénese, desenvolvemento e ferramentas de traballo a moi diversas disciplinas e armazóns teóricas deste e do pasado século: antropoloxía lingüística, etnografia da comunicación, pragmática, análise da conversa, etnometodoloxía, filosofía, sociolingüística interaccional, psicolingüística etc. (Calsamiglia e Tusón 1999: 19-26). Porén, entendemos que é a partir da figura de Norman Fairclough -especialmente coa súa obra Critical Discourse Analysis: The Critical Study of Language (1995)- que se sentan as bases para o estudo crítico da lingua(xe), entendendo por discurso unha práctica vehiculada lingüisticamente e determinada por unha estrutura social nun contexto dado.

Máis contemporaneamente, teóricos como van Dijk continuaron con esta liña a desvendar o funcionamento ideolóxico do discurso cotián e sistematizaron algúns dos métodos, trazos e obxectivos deste programa investigador. @s analistas crític@s do discurso verían os microeventos comunicativos e as macroestruturas sociais como inexorabelmente ligadas. Os primeiros, entón, non poden ser considerados só con base na súa significancia nunha dada situación local, no seo da interacción concreta en que se producen, posto que toda acción contribúe á reprodución de macroestruturas (Fairclough 1995: 34). Tanto se os enunciados dun falante apuntan á asunción da corrente indicada polos condicionantes socioculturais en que ocorre unha interacción local, como se os desafían e transgriden, a práctica de acción social que se produce no discurso oral está sempre vertebrada polo uso de tácticas orientadas localmente (Erickson 2004: 174). A ACD parece resultar un dos mellores aparellos teóricos para capturar con rigor esa estreita relación entre o local e o global na fala, se asumirmos que toda práctica comunicativa acontece nunha ecoloxía inmediata da comunicación cotiá, constrinxida polo ambiente físico e social.

Consecuentemente, van Dijk considera que a $\mathrm{AD}$ debe dar atención aos diferentes niveis de análise a que se prestan os textos, enunciados e interaccións, e polo tanto, asumir que "an interdisciplinary approach to discourse cannot be limited to structural analysis of its various levels or dimensions but also needs

O compendio editado en 1997 por Anna Livia e Kira Hall, Queerly Phrased, marca o pistoletazo de saída neste sentido. Véxase, para un exemplo contemporáneo, amplo e representativo, Ehrlich, Meyerhoff e Holmes 2017, un dos mellores readers dispoñíbeis sobre o asunto. 
to pay attention to cognitive processes and to memory representations of discourse" (van Dijk 1995a: 5). Non só importa a lingua, senón todos os mecanismos activos na cognición, na interacción, na sociedade, na cultura. Neste proceso de análise múltiple acentúase a relevancia dos procedementos de interpretación subxectiva, como pode ser o caso da empatía cos obxectos de interpretación ou a biografía do propio investigador para coas cuestións que analizará (Ibid. 8), como é o noso caso. Isto ten a ver coa premisa da ACD de toda análise do(s) discurso(s) ser por natureza unha análise ideolóxica (Payrató 2003: 138-139), no sentido de que é unha análise de carácter cualitativo centrada no contido e cuxa natureza é instrumental (Ibid. 10). As funcións sociais dos construtos ideolóxicos, que se localizan entre as estruturas sociais e as estruturas das mentes dos membros da sociedade (van Dijk 1995b: 21) serían, entre outras, permitir aos membros dun dado grupo a organización do seu grupo con base na admisión, a coordenación das súas accións e obxectivos sociais, a protección dos seus recursos ou o acceso a tales recursos no caso de seren grupos disidentes ou contrarios (Ibid. 19). Unha eventual comunidade (discursiva) homosexual, que desde xa problematizamos, estaría inmersa nesta maré de vectores ideolóxicos, nunha comprensión intragrupal mais tamén en relación á norma heterosexual, con distinta organización e diferentes recursos.

Malia isto último, non é factíbel operar con ecuacións reducionistas que vexan a sexualidade como un único parámetro que actúa, ademais, de maneira unívoca. A ACD, afortunadamente, dado o seu carácter interdisciplinar, non está allea aos novos panoramas socioeconómicos e culturais a nivel global. Para un rigoroso e interesante estudo da linguaxe nesta contemporaneidade fluída e fragmentada e para a análise da circulación de discursos -non só sobre sexualidade- nos circuítos de comunicación mainstream, é necesaria unha ollada xa non á diversidade ou á variación, senón á superdiversidade. Tomando a noción de "superdiversidade" de Vertovec, J. Blommaert e outros estudosos teñen defendido unha nova axenda para a investigación linguística (Blommaert e Portman 2011: 5). Apoiándose en nocións como a de "comunidade de prática", "institucións" ou "redes", as representacións e interaccións discursivas ultrapasan o marco da idea tradicional de "comunidade de fala", como se verá na disposición dos informantes que gravamos neste traballo. A lingua é entendida, pois, como máis un recurso ou mecanismo semiótico no seo da lingüística da comunicación e, se aceptarmos que debemos movernos desde a idea de "linguaxe" en sentido estrito até a "semiose" como un foco de inquérito, e desde a lingüística até unha nova semiótica sociolingüisticamente conformada, o noso espazo de actuación disciplinar alárgase (2011: 6). O significado é agora unha noción vertebrada multimodalmente onde a indexicalidade xogará un papel fulcral; na sexualidade, non poderiamos entender o que hai de comunicativo e ideolóxico sen atención a este aspecto que resitúa a textualidade e a referencialidade nos parámetros da superdiversidade. Quizais, nunha visión multiescalar do contexto en que o significado se vai actualizando, a sexualidade, canda a dimensións indentitarias como a clase social, a etnicidade, o xénero ou a xeración, poida ser vista como "operating at the most micro-level of interactional process, as resources that participants can draw upon when making sense of what's going on in a communicative event" (Ibid. 10).

A "comunidade de práctica" que mencionamos na disertación blommaertiana supón un novo concepto mediante o cal estudar o discurso e a súa relación coa construción identitaria. Esta idea enormemente útil na $\mathrm{ACD}$, que foi tomada de Lave e Wenger e aplicada ao xénero (Bucholtz 2017: 82) por Eckert e McConnel-Ginet (1992), descansa sobre tres piares: o compromiso mutuo, a empresa conxunta e o repertorio compartido; e é definida como un grupo de persoas con intereses comúns que desenvolven e comparten formas de vida, crenzas e valores (Bengoechea 2015: 182-183). Interésanos neste punto debido a que os nosos informantes, que tradicionalmente poderían ser clasificados como non típicos, son chamados para a investigación académica, reconsiderando así a periferia no nivel dos individuos estudados na análise lingüística. Como indica Moore (2010: 125), afástanos de ver os informantes nunha perspectiva unitaria, co risco de reproducir estereotipos e marxinar comunidades que, se vistas nos seus propios termos, resultarán moi interesantes.

Por último, cómpre salientar a dimensión aplicada da ACD como un conxunto de actores e ideas que procuran fomentar o pensamento crítico e colaborar para unha mudanza real na sociedade. Loitar contra a opresión derivada das relacións de poder e vehiculada a través da lingua e da comunicación parece ser unha pretensión fundamental: "If we could find the 
root cause of linguistic discrimination in a panhuman, natural struggle for power, then perhaps we could solve the problem by redirecting power relations" (Johnstone 2008: 269). A homofobia, como claro exemplo para as liñas que forman o presente estudo, sitúase nesta posición de mecanismo lingüístico ao servizo das prácticas e dos grupos de poder. Porén, a ACD está á altura destes procesos cando pon o foco no carácter transformativo e mutábel das estruturas sociais, tamén das que exercen o poder ao ostentaren a hexemonía. A chave reside en ofrecer ao coñecemento humanístico actual unha boa síntese das tradicións académicas para que os aparellos teóricos poidan funcionar sen ficaren asépticos e distantes de quen, ao cabo, son os seus mecenas: @s falantes.

\subsection{O papel (lingüístico) da identidade}

Un dos contributos centrais ao estudo da lingua en relación á(s) identidade(s), sen o cal sería practicamente imposíbel a viaxe que estamos a propor, é a obra de John E. Joseph, Language and Identity (2004). Nela analiza os diferentes tipos de relación entre a actividade lingüística e as variedades de identidade, así como o desenvolvemento na historia humanística contemporánea do relacionamento destes dous complexos. Nun nivel xeral, existen identidades individuais e identidades grupais e colectivas (estas últimas posúen un carácter máis abstracto), ambas construídas en relación co contorno e cos interactantes. Unha parte deste fenómeno vén dado pola natureza basicamente lingüística da identidade, entendendo a identidade como unha subcategoría da representación: lemos a identidade dos nosos interlocutores nas palabras que ouvimos. Mais de onde vén e como se constitúe esta dimensión nun dado suxeito pensante?

Dentro das ciencias sociais, un dos debates mais axitados, precisamente, foi o da distinción entre o carácter esencial e o carácter construído da identidade, entre outros conceptos e categorías das sociedades humanas. Mentres o esencialismo defende que o feito de 'ser home' ou 'ser muller' (ser 'gay' ou ser 'lesbiana', 'ser galega' ou 'chinés' ou 'croata'), é explicado pola simple pertenza a esas categorías, con anterioridade ao desenvolvemento nunhas circunstancias sociais, políticas, materiais e culturais dadas, o construcionismo argumenta que estas últimas son precisamente os mecanismos que deseñan a(s) identidade(s). Non existe, daquela, algo previo á socialización que poida explicar a auto- e a heteroclasificación. $\mathrm{O}$ xénero, por exemplo, entendido como a repetición estilizada dunha serie de accións e enunciados (Butler 2010), conforma a sociedade en homes e mulleres, e suporía a construción social da distinción biolóxica entre homes e mulleres. Coa sexualidade acontece algo parecido xa que a categoría 'homosexual' é tan natural canto sexa coherente cunha historia desa etiqueta e das prácticas ás que se liga, en función dun ambiente mediado polo poder (Foucault 2006 [1976]).

Segundo Judith Butler (2004, 2010), a identidade é unha práctica discursiva e tamén unha performance con todas as connotacións de non esencialismo, versatilidade e máscara que implica. Ao conceptualizarmos o poder como un mecanismo dinámico, entendemos como se produce e desenvolve o seu funcionamento na interacción discursiva, con maior saliencia aínda se o ligarmos ás identidades institucionais, dado que as institucións son normalmente construídas para e por grupos e individuos que ostentan o poder. A heteronorma ou o heteropatriarcado e a escola son, obviamente, institucións. Xa que as nosas interaccións diarias precisan de constantes performances, operativas de forma estratéxica en función das demandas do contexto comunicativo, a identidade é un termo útil para describir este fenómeno. É por iso que entederemos identidade por "the outcome of processes by which people index their similarity to and difference from others, sometimes self-conciously and strategically and sometimes as a matter of habit" (Johnstone 2008: 151).

\subsubsection{A identidade na interacción: unha pro- posta de estudo sociocultural}

O marco último de análise que manexamos a este respecto é a proposta de Bucholtz e Hall (2005), segundo a cal a identidade se articula como un fenómeno relacional e sociocultural que emerxe e circula en "local discourse contexts of interaction" (2005: 585-586) e non como unha estrutura estábel localizada primariamente na psique do individuo ou en categorías sociais fixadas, como argumentamos supra. A definición ampla e abranxente de identidade como "the social positioning of self and other", que alarga a concepción de Johnstone, enmarca ben o seu carácter operativo en múltiples niveis simultaneamente. As autoras estabelecen cinco principios fundamentais para o seu estudo, que pasamos a esbozar:

(i) O principio de emerxencia. As identidades emerxen na interacción como fenómenos 
sociais e culturais, e son constituídas como socialmente reais exclusivamente mediante o discurso, sobre todo mediante a interacción. As macrocategorías, coa súa relativa coherencia ideolóxica, son constrinxidas polas realizacións prácticas e reais na comunicación nun determinado contexto social.

(ii) O principio de posicionalidade.@susuari@s da lingua xeralmente oriéntanse cara a categorías identitarias locais máis do que cara ás categorías sociolóxicas que manexan@s analistas. Eles/as deseñan posicións interaccionais, roles temporais e orientacións discursivas que contribúen á formación de subxectividade e intersubxectividade, da mesma maneira que as grandes categorías identitarias de corte sociolóxico e etnográfico. Os diferentes tipos de posición ocorren tipicamente de maneira simultánea nunha simple interacción.

(iii) O principio de indexicalidade - o mecanismo principal polo cal se constitúe a identidade no discurso. A indexicalidade envolvería a creación de ligazóns semióticas entre formas lingüísticas e significados sociais e ocorrería en todos os niveis da estrutura e do uso lingüísticos (uso explícito de etiquetas e categorías identitarias, implicatura e presuposicións, formas sintácticas e pronominais, expresións da modalidade etc.).

(iv) $\mathrm{O}$ principio de relacionalidade. As identidades nunca son autónomas ou independentes senón que adquiren significado social en relación a outras posicións identitarias avaliábeis polos individuos ou en base a outros actores sociais. Estípulanse algúns pares de binomios que vertebran as relacións implicadas na construción identitaria. (A) Adecuación/distinción: a adecuación explica o achegamento das posicións individuais como non idénticas senón suficientemente semellantes ás pretensións interaccionais dos outros interlocutores; a distinción, pola súa banda, depende da supresión de similaridades que poderían dinamitar a construción da diferenza. (B) Autenticación/ desnaturalización: a autenticación consiste nun proceso social disposto no discurso en que se asume a autenticidade; o proceso oposto é denominado desnaturalización. (C) Autorización/ ilexitimación: a autorización implica a afirmación ou imposición dunha identidade a través de estruturas institucionalizadas de ideoloxía e poder, quer local, quer translocal; polo seu lado, a ilexitimación adhire ao modo en que as identidades son censuradas, prohibidas ou simplemente ignoradas por esas mesmas estruturas. (v) $\mathrm{O}$ principio de parcialidade. A identidade, dado que é un fenómeno relacional, será sempre parcial, producido concretamente grazas ás configuracións situadas contextualmente e informadas ideoloxicamente dun mesmo e do outro. Deste modo, a identidade "is one kind of social action that agency can accomplish" (2005: 606).

Para o presente traballo, focamos o interese na identidade sexual, unha dimensión que, como a continuación explicaremos, foi bastante revisitada e problematizada nos últimos tempos.

\subsection{A sexualidade contemporánea e os estu- dos discursivos: algúns gritos de emerxencia}

Cando Deborah Cameron traza unha pequena historia do panorama investigador sobre os termos que nos convocan na presente epígrafe, no seu artigo "Language, Gender and Sexuality: Current Issues and New Directions" (2005), sitúa como punto de partida Robin Lakoff e o seu Language and Woman's Place (1975). Nesa obra, Lakoff toma como premisa a subordinación da muller a causa da dominación e da desigualdade de xénero, que se reflectiría no comportamento lingüístico diferenciado dos homes. Non era exactamente o primeiro traballo feminista sobre a linguaxe, mais alcanzou unha grande fama na súa defensa dunha tese que estipulaba para as mulleres un déficit lingüístico-comunicativo derivado da opresión do poder masculino institucionalizado, como ben explica Mercedes Bengoechea, polo que "las norteamericanas se ven ante el dilema de expresarse como «señoras» o mostrarse como hablantes competentes" (2015: 138). Pola súa banda, en 1990, Deborah Tannen tira do prelo o segundo grande fito da lingüística feminista do século XX -You Just Don't Understand-, a súa teoría da diferenza cultural para explicar, mediante a socialización e a pertenza a subculturas diferentes, a distancia lingüística entre homes e mulleres.

No entanto, nos anos noventa, coa chegada de Judith Butler, Teresa de Lauretis e outras pensadoras da sexualidade, ábrense novos camiños nos estudos de linguaxe e xénero, xa desde o achegamento feminista posmoderno en que este traballo se enmarca. Nesta nova ollada, Greco (2012: 570) apunta que a investigación pasou a se centrar en como as normas e as cuestións de xénero (se) construían e deconstruían no discurso máis do que en procurar diferenzas lingüísticas esenciais con base no binarismo sexual. Isto desemboca na chamada 
Lingüística Queer actual, que nace con Anna Livia e Kira Hall (1997) no libro Queerly Phrased (Borba 2015: 99).

Coa diversificación dos tipos, estruturas e categorizacións de conceptos como "identidade", "masculinidade(s)" e "feminidade(s)", no xiro posmoderno, os estudos de lingua e xénero abríronse á consideración teórico-analítica da sexualidade na fala. Comezaron a publicarse traballos nesta liña que se centraban especialmente na identidade sexual "como forma de identidad social que, aunque basada en el deseo, va más allá del objeto de deseo"; e na sexualidade, "no tanto como práctica sexual, sino como la comunicación e inteligibilidad del deseo" (Bengoechea 2015: 199).

De feito, no presente máis actual, a investigación en lingua e sexualidade non parte dunha categoría sexual como gay para tratar de estabelecer unha lista fechada de características fonéticas, morfolóxicas ou pragmáticas, senón que analiza a emerxencia de aspectos identitarios ligados a certas categorías no discurso real, isto é, a lingua en uso no modo en que nela funcionan interdiscursiva e intereseccionalmente cuestións ligadas á sexualidade. A Lingüística Queer é entendida, por tanto, como "una disciplina que se propone investigar desde una perspectiva crítica las relaciones entre lenguaje y heterosexualidad normativa" (Ibid. 221), pois a institución contra a que atenta a teoría queer é, digamos, a heterosexualidade (compulsoria). Para Butler, a "matriz heterosexual" é o mecanismo biopolítico que disciplina e ata a relación entre sexo, xénero e sexualidade. A heteronormatividade 4 funciona, entón, como aquilo que vertebra, con carácter crítico, as aproximacións queer ao estudo do discurso.

Para o noso traballo, a sexualidade non heteronormativa, neste caso "homosexual", é un aspecto de estudo emancipatorio e interesante xa que se enmarca no que Giddens chama "sexualidade plástica", no sentido de que é descentrada, liberada de necesidades reprodutivas e democratizadora na medida en que liberta a sexualidade da hexemonía fálica (1998: 4). No entanto, falarmos de homosexualidade podería supor estar a impor nos informantes unha categoría sexual esencialista, polo que se fai imprescindíbel a consideración dalgúns factores.
Por un lado, a congruencia e o interese dunha análise interseccional da sexualidade, en que non se apague a importancia dunha aproximación multinivel de corte bourdieuano, aínda que se focalice en maior medida a análise da sexualidade sobre "the ways in which dynamic systems of social organization mutually constitute one another" (Levon e Mendes 2016: 1112). O prisma a través do que analizar o corpus debe conxugar as teorías da indexicalidade de Ochs, reformuladas por Penelope Eckert, co emerxentismo, coa performatividade ou coa globalización como actores relevantes.

Este carácter aberto da operatividade do xénero fundamenta a necesidade de relacionar as categorías macro coas análises micro para, así, apagar a "omnirelevance du genre dans les pratiques sociales" (Greco 2015: 141). Contodo, no seo do debate entre a análise da conversa e a antropoloxía lingüística sobre o funcionamento do xénero e da sexualidade na comunicación, concordamos coas palabras dos etnometodoloxistas West e Zimmerman (apud Ibid.): "in virtually any situation, one's sex category can be relevant, and one's performance as an incumbent of that category (i.e., gender) can be subjected to evaluation". A tarefa de explicar esta cuestión recae, ao noso ver, na ACD, polo seu procedemento entre o microcomunicativo e o macroestrutural. No nivel micro, a teoría queer permite pór ás avesas a interacción, a identidade dun mesmo e a heteropercepción, mais no nivel macro existe unha lectura social das persoas e dos enunciados que non está allea aos condicionantes materiais e socioculturais. Esta encrucillada atrapa $\mathrm{o}$ interese e a dificultade do presente traballo.

\section{Metodoloxía e traballo de campo}

Para o presente estudo, contamos coa colaboración de tres rapaces de entre vinte e trinta anos, todos eles galegofalantes e que se autodefinen como persoas non heterosexuais. Estes, basicamente, eran os requisitos previos da investigación, acoutada ao estudo de suxeitos "varóns", ou lidos socialmente como tal, por unha cuestión de tempo e complexidade. A pesar de ser difícil encontrar este tipo de informantes, mesmo sendo o investigador unha persoa próxima destas características e de posíbeis circuítos

4 "the system which prescribes, enjoins, rewards, and naturalizes a particular kind of heterosexuality -monogamous, reproductive, and based on conventionally complementary gender roles- as the norm on which social arrangements should be based" (Cameron 2005: 489). 
a elas asociados, finalmente constituíuse un grupo de conversa. Prescindimos de homes heterosexuais para crear un espazo discursivo cómodo que permitise a liberdade e a boa disposición para o debate sen interferencias da "masculinidade hexemónica" (Connell 1998) e da "violencia masculina" (Bourdieu 2015), acentuadas no caso de varóns heterosexuais. Neste sentido, unha cuestión clásica que preocupaba á sociolingüística, o paradoxo do observador de Labov (1983), perde a súa relevancia porque, do punto de vista metodolóxico da ACD, a interferencia do investigador pode ser procurada. O verdadeiramente importante é cara onde se quere orientar esa influencia desde enriba que exerce quen estuda os intercambios lingüísticos, tamén situado dentro da ecoloxía comunicativa. Sempre suxestionamos os nosos informantes e, no noso caso, a escolla dos propios falantes e a selección de estímulos para a conversa, aspectos que explicaremos deseguido, enfócanse claramente cara ao tratamento crítico da (homo)sexualidade.

Os tres participantes descoñécense entre eles e teñen como único nexo o investigador, co que manteñen diferentes graos de relación e coñecemento. Falarán en todo o corpus de historias que lles ocorreron durante a súa vida en relación coa sexualidade e de como estas os fan construírse, posicionarse no mundo e entender a sociedade. Saben que conversan entre pares, "para" alguén do seu in-group, nun lugar discursivo en que a homoafectividade, a homofobia ou a socialización da sexualidade son temas comúns. Coa pretensión de explotar estes aspectos, decidimos empregar estímulos audiovisuais como fotografías e vídeos, xa que a proposta de excertos de texto escrito podería implicar que os falantes se cinxisen á literalidade e mera textualidade dos enunciados alí presentes. Para evitar a autoridade exercida pola palabra grafada, deseñamos dúas actividades para a interacción: en primeiro lugar, a reprodución do primeiro minuto dun vídeo xornalístico realizado por El País en que o profesor de secundaria José Joaquín Álvarez fala sobre a súa experiencia persoal e docente dando charlas sobre a homosexualidade e (n) a escola; e, en segundo lugar, a mostra de catro fotografías de dous persoeiros recoñecidamente "homosexuais" no contexto do Estado español.
Os informantes cubriron con antecedencia ás gravacións tanto unha ficha con datos persoais como unha autorización para a cesión dos datos con fins académicos, que tamén pronunciaron oralmente. No inicio da actividade conversacional que sería gravada, no relativo ao primeiro ítem, reproduciuse o vídeo dúas veces consecutivas coa presenza do investigador e despois abandonouse a sala deixando unha gravadora sobre a mesa en que os informantes estaban sentados. Desta maneira, eles seleccionaron aqueles aspectos que consideraron máis relevantes e útiles para a conversa, destacando as partes que máis lembraban e con que máis se identificaban. O vídeo presenta como temas centrais a saída do armario no contexto familiar, a homofobia, a visibilidade dos adolescentes LGTB na escola, ou o deber pedagóxico desta última institución no empoderamento e valorización da diversidade sexual, polo que parece resultar un input bastante suxestivo. Para o segundo ítem, pola súa banda, deixáronse sobre a mesa as imaxes que a seguir reproducimos (e mais outras dúas dos mesmos suxeitos, en actitudes e espazos semellantes), coa intención de que contrastasen e avaliasen as figuras que nelas se presentan. Á esquerda, temos Jorge Javier Vázquez, coñecido xornalista e presentador na prensa rosa española, e recoñecidamente homosexual. Á dereita, observamos Rodrigo Cuevas, artista e performer asturiano que viviu na Galiza durante algúns anos, dedicado á revisión performativa da tradición e do folclore, e que se define a si propio como "asturiano, rural y sexy".
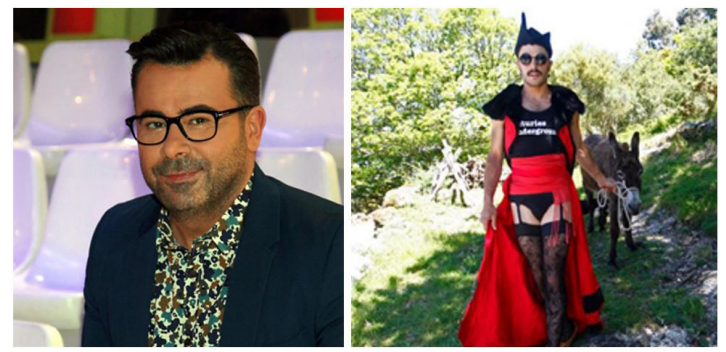

Figura 1. Jorge Javier Vázquez e Rodrigo Cuevas

Após mostrar as imaxes preguntando se recoñecían as figuras, o investigador abandonou a sala e, igual que no anterior paso, deixou unha gravadora sobre a mesa.

En definitiva, recompilamos un total de 50 minutos e 42 segundos, dos que obtivemos 
unha transcrición de 46 minutos e 55 segundos, realizada co programa $\mathrm{ELAN}^{6}$ seguindo os criterios de transcrición do proxecto CORILGA ${ }^{7}$ (Corpus Oral Informatizado da Lingua Galega) do Instituto da Lingua Galega da USC. Unha vez feitas e revisadas, foron exportadas e sistematizadas. Se “...there are almost as many ways to transcribe speech as there are researchers who do so", e xa que "...there is no single generally accepted way to represent speech on the page", unha transcrición será sempre e necesariamente a representación parcial da fala recollida e as decisións do transcritor sobre o que incluír e excluír, sobre o que representar e como facelo, teñen consecuencias prácticas e teóricas (Johnstone 2008: 23). Noutras palabras, na transcrición é onde comeza o tratamento dos datos e este feito "implica tomar una serie de decisiones que forman ya parte del análisis y que lo afectan" (Calsamiglia e Tusón 1999: 357). É por iso que semella obvio neste aspecto optar polo maxisterio de grupos consolidados de investigación e de proxectos rigorosos de estudo da lingua oral, como é o CORILGA.

Para o presente traballo, a implicación persoal do investigador con narrativas persoais como pode ser a "saída do armario", a aceptación ou a comunicación nas redes máis achegadas da sexualidade non normativa, resulta fulcral para entender eses procesos. Os informantes comparten parte da súa identidade grupal co autor destas liñas e existe, xa que logo, unha certa empatía e familiaridade na comunicación sobre este asunto: "the researcher therefore needs a simultaneous familiarity with their data's contents and relevant literature" (Murray, apud Benwell e Stokoe 2006: 144-145).

\section{Análise do corpus}

Nesta sección, presentamos algúns fragmentos das conversas recompiladas para, á luz das cuestións teóricas e metodolóxicas comentadas nas anteriores epígrafes, botar luz de maneira global e non exhaustiva sobre algúns aspectos socio-discursivos e culturais que consideramos relevantes na intersección entre discurso e sexualidade.

\subsection{Etiquetas e termos identitarios}

Nun dos primeiros enunciados que intercambian os falantes -que lembramos que non se coñecían de nada entre si-, o I1 pregunta sobre que deberan falar, non sen un certo escándalo ou sorpresa por parte dos outros: "sobre o vídeo ou sobre o ser maricón en xeral?", dirá. A partir dese momento, usará o descritor "maricón" de forma constante, malia a ausencia de seguimento por parte dos seus interlocutores. É máis, empregará tamén outras palabras que toman por base o dito termo, en xeral marcado como despectivo: "eso en primeira instancia paréceme unha puta mariconada, o de ir collidos da puta man". Por tanto, observamos unha conduta diferenciada entre os informantes: o I1 avoga polo termo "maricón", o I2 é inicialmente remiso a esta fórmula e o I3, que usa menos etiquetas, estaría condutualmente no medio. No cómputo xeral, obtemos o seguinte gráfico:

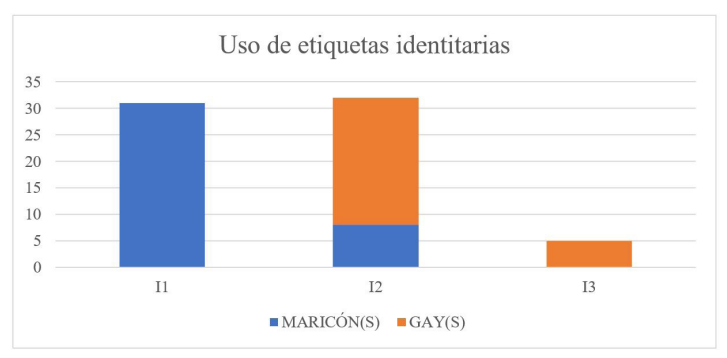

Gráfico 1. Uso de etiquetas

Se botarmos unha ollada a través de todo o proceso comunicativo desde o seu inicio até o final da segunda gravación, observaremos como este aspecto se negocia. O termo en concorrencia a "maricón", "gay", é puntualmente apagado en favor dunha aceptación común do primeiro dos termos, se ben que, como mostraremos a continuación a través dos enunciados do I2, tal aceptación estea moi marcada contextualmente.

Outras etiquetas como "homosexual" ou "mariquita", moito máis infrecuentes (a primeira con catro ocorrencias e a segunda con só unha), aparecen na materialidade discursiva con certas connotacións. Vexámolo nos seguintes extractos:

6 Trátase dunha ferramenta lingüística de transcrición e anotación multinivel, desenvolvida polo Max Planck Institute for Psycholinguistics. Dispoñíbel en: https://tla.mpi.nl/tools/tla-tools/elan/.

7 No sitio web do proxecto pode encontrarse unha versión destes criterios, accesíbel en: http://ilg.usc.gal/corilga/. 


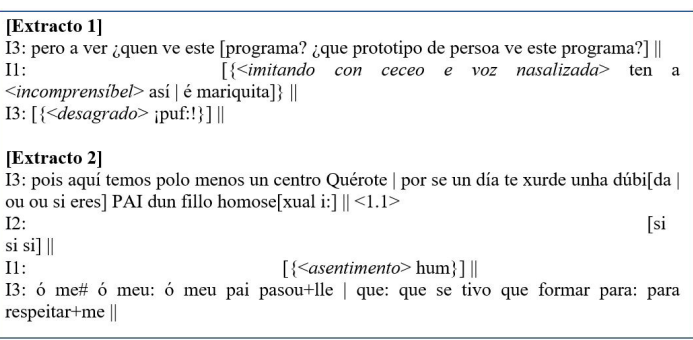

Mentres o primeiro deles, coa forma indexical -ita, reflicte un estilo de lingua oral prototipicamente gay (emúlanse características fonéticas da famosa "fala gay"8), na lectura social xeral, creado por repetición e fosilización ideolóxica de "stances", o segundo evoca un contexto marcadamente clínico. Os centros de (in)formación sexual que financian as Administracións implican a presenza dun termo como "homosexual", máis formal que "gay" ou "maricón" e, especialmente, presente no discurso patoloxizante das sexualidades disidentes, como ben explica Foucault (2006 [1976]). O termo "homosexual" só se afianza como tal no século XIX, onde os dispositivos de saturación sexual agroman con máis forza, entre un duplo impulso biopolítico e xurídico de pracer e poder: "placer de ejercer un poder que pregunta, vigila, acecha, espía, excava, palpa, saca a la luz; y del otro lado, placer que se enciende al tener que escapar de ese poder, al tener que huirlo, engañarlo o disfrazarlo" (Ibid. 46).

Vemos, pois, que se van negociando os usos das dúas etiquetas máis relevantes, tinxidas de cuestións ideolóxicas. O I2 reproducirá unha clásica expresión que escoitou nunha ocasión a un veciño, pai de familia: "es que una cosa es ser gay y otra cosa es ser maricón". Para alén do discurso reproducido, este informante emprega o termo maricón cando o contexto do enunciado é de disgusto: "Eles pensan que ser maricón é en plan (...) agh, maricón! Tes que demostrar que hai gays aos que lles gusta o fútbol, hai gays que fan remo...". Non por acaso, "gay" é a fórmula preferida na linguaxe pública, en canto "maricón" remite ás vivencias persoais de corte homofóbico, especialmente no ámbito escolar.

Por que, entón, o I1 é perseverante na súa naturalización e verbalización consciente da denominación "maricón"? Cremos que por dúas cuestións: unha de carácter consciente e abertamente política; a outra, quizais moito máis inconsciente, de tipo pragmático e socialmente situada.

A primeira delas é a denominada resemantización ou reapropiación discursiva, na liña de cuestionamento da linguaxe de odio de Judith Butler (2004 [1997]). Aquilo que nos fere lingüisticamente pode ser interiorizado e liberado do seu valor pexorativo se for posto en circulación no seo de comunidades de resistencia "en formas más afirmativas". Dentro e ás veces como pode ser o caso-contra as posicións dentro desas comunidades. Expresará así a súa tese:

Los argumentos en favor de una contra-apropiación o de una representación nueva del habla ofensiva se ven claramente cuestionados por la posición según la cual el efecto ofensivo del acto de habla está necesariamente relacionado con el acto de habla, con su contexto originario o perdurable, o incluso, con las intenciones que lo animan o con sus utilizaciones originales. $\mathrm{La}$ reevaluación de términos como "queer" sugiere que el habla puede ser "devuelto" al hablante de una forma diferente, que puede citarse contra sus propósitos originales y producir una inversión de sus efectos. (2004 [1997]:34-35)

A segunda das implicacións que acreditamos estean a funcionar na verbalización de etiquetas explícase, en parte, grazas ao seguinte treito:

8 Retrotraéndonos aos anos setenta, debido ao estoupido e consolidación de movementos de liberación sexual e de demanda de dereitos, o cerne dos traballos lingüísticos a este respecto centráronse no léxico, na procura dunha especie de "fala gay/lésbica" que sustentase a política identitaria imperante. Posteriormente, como indica Bengoechea (2015), deuse protagonismo á fonética, segundo dos grandes temas de relevancia para os lingüistas homosexuais que decidiron adentrarse no binomio lingua-sexualidade. Neste campo de traballo, teorizábase sobre unha posíbel voz gay, con características propias a nivel prosódico, diferenciais dos heterosexuais e identificativas por excelencia dos homosexuais. Por último, no ámbito máis pragmático-discursivo, diversos autores investigaron sobre a semiótica, a retórica ou a comunicación non verbal gay, sen chegar a grandes e consensuadas conclusións. Para outros traballos que recollen o percurso académico de estudo de lingua e homosexualidade, véxanse Bucholtz 2017 e Cameron e Kulick 2003; especialmente, o capítulo 4.

9 En termos de Bucholtz e Hall, "the display of evaluative, affective, and epistemic orientations in discourse" (2005: 595), cuxa acumulación desembocaría en maiores e máis permanentes estruturas de identidade, que responden ao concepto de "estilo". 


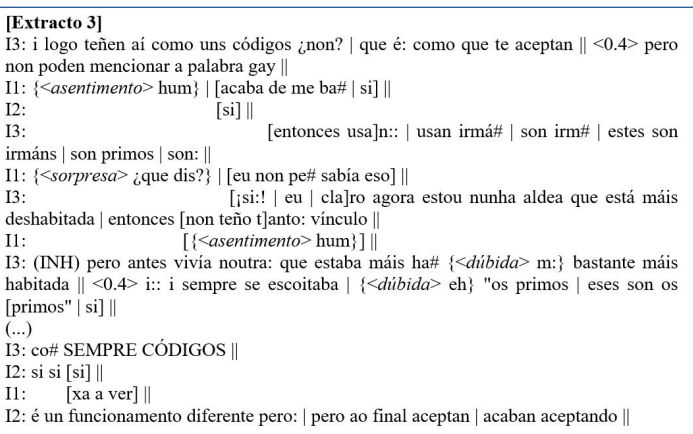

Digamos que para que algo sexa ofensivo (e, xa que logo, contra-ofensivo) ten que ser reproducíbel: "el lenguaje que contrarresta las ofensas debe repetir aquellas ofensas sin por lo tanto llegar a recrearlas" (Ibid. 71). Eses códigos de que falan os informantes, na liña da definición identitaria como "objet de travail" (Greco 2016:143), son apreciados por eles como dignos de valoración, dado que o I1, por exemplo, foxe da nominalización eufemística que supoñen os termos alternativos a "maricón". Decidir como lle chamamos a algo "constitute a claim about it" (Johnstone 2008: 58), tanto dentro do grupo como fóra e, é máis, non se pode integrar aquilo que non se pode nomear. Por tanto, esta estratexia do I1, ao fío da presente segunda razón que estamos a esbozar, é "popularizante" ao tempo que combativa. Non só desconcerta os seus propios interlocutores, con quen se liga identitariamente, senón que ataca as formas lingüísticas de representación (agresiva) dos outros, aproximándose de designacións que encaixan co habitus da maior parte de actores na súa comunidade local. Esta manipulación discursiva das etiquetas, de carácter paradoxalmente naturalizador, activa resistencias na conversa sen caer nunha actitude resistencialista que o totalice só con base nunha determinada condición sexual.

Dunha perspectiva xeral, Calsamiglia e Tusón (1999: 45) claman pola elaboración dese "discurso de resistencia" despois de asegurar que "los grupos marginados en una sociedad (...) poseen menos «capital» verbal y comunicativo", e o que teñen "vale menos en el mercado de los valores comunicativos", seguindo Bourdieu. Mais ten pouca competencia comunicativa e pouco valor o capital verbal dun homosexual con grande poder adquisitivo nunha grande cidade europea, se o compararmos co caso que aquí estudamos? Realmente é a identidade sexual dos interlocutores o que lles resta competencia e valor? Pode ser, na nosa opinión, demasiado inxenuo crer isto, unha vez que a comunidade de práctica non é sexualmente homoxénea. Concretamente, o termo "gay" no que se debruzan no anterior extracto non é popular nesas súas comunidades de práctica non urbanas, onde os códigos operativos a respecto da sexualidade teñen "un funcionamento diferente". Porén, espérase que se autodenominen intragrupalmente como tal. Por iso, na nosa opinión, estamos máis ben ante unha cuestión de clase no referente a estas estratexias que se serven dos valores do mercado linguístico, con atención a dinámicas de poder local, e das categorías socialmente encriptadas. En 4.3 aprofundaremos, precisamente, en cuestións xeográficas e socioeconómicas en relación á fala, mais parece que o discurso de resistencia que aquí se elabora pode ser mellor explicado con base en identidades que transcenden a cuestión da sexualidade. O mecanismo para seren aceptados direcciónase ao vínculo, en termos de comunidade, e non cara á diferenza, en termos de (exclusiva) identidade sexual.

\subsection{O outing como fenómeno discursivo: na- rrativas persoais sobre a "saída do armario"}

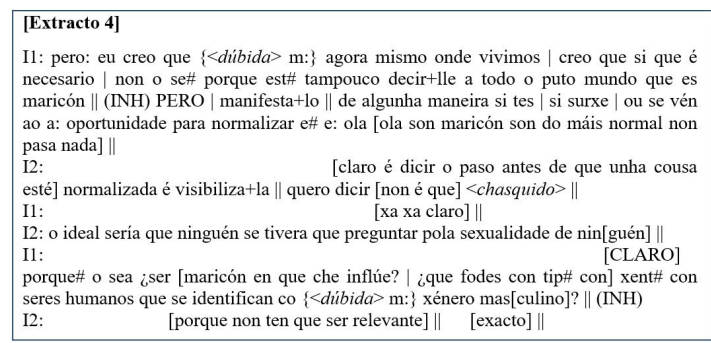

O tema da saída do armario é tratado en diferentes ocasións ao longo da conversa, posto que vertebra o vídeo que empregamos como estímulo na primeira parte das gravacións. $\mathrm{O}$ profesor que o protagoniza narra a súa experiencia persoal de confesión á súa nai do feito de a súa condición sexual non ser normal -isto é, non heterosexual-e, por tanto, ser merecente de verbalización consciente e de explicación social. Os informantes discuten sobre a cuestión desde un posicionamento concreto e local, sen perderen de vista, nun segundo plano, a consideración superestrutural da sociedade.

Pódese patentar esta dicotomía na disposición sintáctica dos enunciados, que se vai constituíndo entre o adversativo e o condicional. Así, o I1 reitera a idea de que aínda considera necesaria unha saída verbal do armario, non tanto unha saída para un propio (sempre máis complexa e primaria), senón para o resto (Liang 1997). De entre estes dous vectores, 
Levon (2015: 20) asegura que as historias en que se narra esta materialización discursiva da sexualidade son historias de autodescuberta e autoaceptación. Non parece ser así no noso caso, en que se matiza a relevancia estratéxica e o sentido do outing. As etiquetas sobre as que nos centramos na anterior epígrafe parecen ser as partículas que indexan con máis forza a identidade na narrativa persoal destes "storied selves", no seo da "storytelling society" (Denzin, apud Benwell e Stokoe 2006: 130): "ou se vén a oportunidade para normalizar e «ola, son maricón, son do máis normal, non pasa nada»". Para eles, ser gay supostamente non inflúe en nada, alén de "foder con seres humanos que se identifican co xénero masculino". No entanto, a identificación no plano discursivo, dado que a homosexualidade non é lexitimada socialmente, supón un mecanismo normalizador dunha condición coa que mesmo os propios falantes non se aliñan en termos de autenticación (Bucholtz e Hall 2005); isto é, non asumen completamente esa suposta "autenticidade gay".

Até tres veces reformula a súa aseveración o I1, nunha escala semántica de progresiva amplitude e xeneralización: "tipos" > "xente" $>$ "seres humanos que se identifican co xénero masculino". Na liña de Mondada e Oloff (2015: 20), a idea da saída do armario provén da natureza asimétrica das relacións e identidades sexuais e vén demostrar a supremacía heterosexual: "porque non ten que ser relevante", di o I2, querendo dicir que, de momento, si o é. A visibilización, na liña do esencialismo estratéxico, é posta contra as forzas de ilexitimación sexual, e visa ese ideal do I2 de ninguén se preguntar pola sexualidade dos outros. De maneira constante, existe un equilibrio negociado entre a indeterminación, da man da non verbalización, e a visibilización normalizadora: "tampouco dicirlle a todo o mundo que es maricón, pero manifestalo dalgunha maneira". Non de calquera maneira, senón de algunha, concreta e contextualmente moldeada, que quebre co silencio sen silenciar outros aspectos e actores comunicativos.

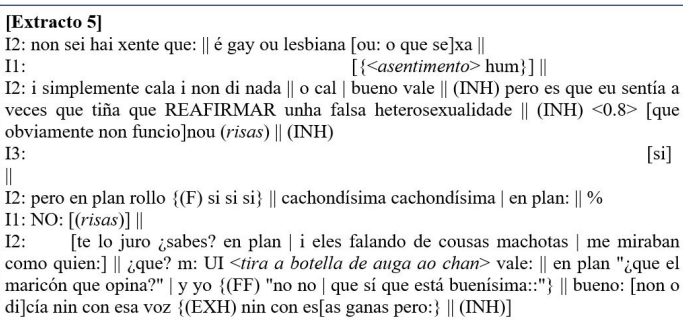

Barrett (1997: 187) reflexiona sobre a saída do armario como camiño unívoco e inevitábel para aqueles suxeitos falantes cuxas sexualidades transgriden a heteronormatividade. Para el, supón un rito de pasaxe que naturaliza os individuos ao darlles acceso á "auténtica" cultura gay. Mais mesmo nesa auténtica cultura gay de que fala o autor existe unha interpelación por parte das estruturas de poder a respecto da normalidade. O I2, neste último fragmento, emprega con bastante transparencia o verbo "reafirmar" cando fala da presión para verbalizar a sexualidade. A condición afírmase; afírmase intelixibelmente. É falada mesmo cando quen a experimenta "cala e non di nada", unha vez que a comunicación cotiá no seo da sociedade comprende o xénero e a sexualidade como elementos de interacción. O falante é obrigado a performar unha falsa heterosexualidade porque o contexto interactivo é construído con parte desa súa identidade.

Neste sentido, o silenciamento non vén de parte de quen exerce a homofobia ("el maricón que opina?"), senón de quen non se verbaliza como disidente sexual ("xente que é gay ou lesbiana ou o que sexa" e non crea lazos discursivos de solidariedade). A violencia verbal heterosexual autoriza o estatuto de interlocutores para os homosexuais xa que só no marco do diálogo é posíbel unha lectura constitutiva da identidade grupal, desde a que realizar efectivamente a exclusión. E cómpre salientar, como ilustra a conversa, a importancia dos espazos escolares que se constitúen en comunidades de práctica: son os seus propios colegas de turma quen o colocan nese lugar enunciativo. Ao non recoñeceren como membro do grupo a un individuo, son capaces de crear as fronteiras lingüísticas que activen a categorización e o poder: "non o dicía con esa voz nin con esas ganas". E aquí esa reformulación que matiza as características fonético-prosódicas tan enfáticas con que trata o seu propio discurso reproducido é abondo ilustrativa: a enunciación emula os aspectos da voz autorizada e o falante sitúase nunha alteridade inconsciente, que o fai ter que esclarecer a súa expresión. A introdución na interacción dese individuo e o requerimento da súa opinión sobre un asunto constitúen un acto de lexitimación e inclusión no in-group que, malia todo, é a base para a agresión identitaria. Especialmente se o asunto for o grande asunto do desexo sexual masculino! Ao cabo, o I2 non deixa de ser lido social e corporalmente como home e precisamente por iso é interpelado en busca da afirmación 
da virilidade, que non só é unha capacidade reprodutora, sexual e social, senón que funciona como ferramenta de violencia, tamén de violencia discursiva (Bourdieu 2015 [1998]: 68). O xénero interaxe coa sexualidade para encamiñar, mediante o xogo lingüístico, a negociación da inclusión/exclusión.

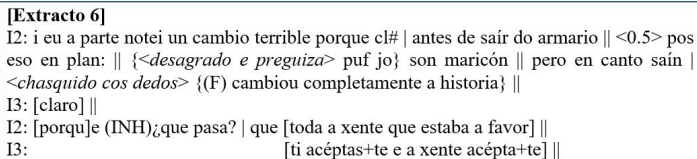

Neste último extracto, observamos como ese estatuto ontolóxico especial que confire a saída do armario pode ser funcional para os falantes. Alén da autoaceptación que leva consigo, este fenómeno, que supón un cambio acusado ("terrible", dirá o I2) a nivel experiencial, é "efectivamente capaz de organizar e representar a experiência da sua própria sexualidade e identidade, pelo menos de um modo suficientemente eficaz para que a sua adopção (ainda que apenas tácita) compense os enormes custos que lhe estão associados" (Sedgwick 2003 [1990]: 26-27).

Desta maneira, éntrase na problemática que confronta tal manifestación identitaria. A autorización dos dispositivos de vixilancia e poder para a non heterosexualidade pasa polo seu recoñecemento identitario discursivo, a pesar de os homosexuais seren suxeitos abxectos a respecto da matriz heteronormativa. Noutras palabras, é necesaria a naturalización do construto que supón a sexualidade para poder existir no seo comunicativo macroestrutural: se non te etiquetares como "gay", situaraste fóra do autorecoñecemento e do recoñecemento alleo, vertebrados polas exixencias institucionais e simbólicas impostas sobre a xestión do coñecemento sociocultural partillado e negociado. Para a conversa concreta que recollemos, a indefinición é factíbel dada a flexibilidade en que opera a adecuación e unha vez que se recoñecen entre eles como pares. En definitiva, por unha "power base" relativamente común (van Dijk 2015: 469), que os fai activaren estratexias mais queer desde a consciencia da súa posicionalidade.

Precisamente antes de pasarmos ao seguinte punto, gustaríanos enfatizar algunha das problemáticas de deslocalización e universalización unívoca da "saída do armario", na liña de Judith Butler, xa que este fenómeno pode supor un modelo homonormativo e metronormativo (Halberstam 2005) que reforce a idea da vida gay como ligada ao consumo, ao matrimonio e ao usufruír determinados privilexios urbanos. Como indica Baker, na súa lectura de Halberstam, "the construction of gay subjectivity is itself embebbed within a narrative of rural to urban migration, which maps the psychological journey of coming onto a physical journey to the city" (2011: 42), cando na verdade son posíbeis -e existen como talmaneiras de expresar as sexualidades non normativas dentro e a través das propias normas das súas comunidades (Ibid. 47). Sendo así, a política -tamén discursiva!- da visibilidade non só pode resultar un fenómeno metronormativo dificilmente aplicábel ás experiencias e contextos de gays, lésbicas e queer de fóra de núcleos urbanos, mais tamén pode apagar, na súa aplicación e requerimento monolíticos, outros tipos de existencia queer alternativos e creativos (Schweighofer 2016: 238). Ao final,

For whom is outness a historically available and affordable option? Is there an unmarked class character to the demand for universal "outness"? Who is represented by which use of the term, and who is excluded? For whom does the term present an impossible conflict between racial, ethnic, or religious affiliation and sexual politics? What kinds of policies are enabled by what kinds of usages, and which are backgrounded or erased from view? (Butler 1993: 227)

\subsection{A mercantilización das identidades e a alternativa agrocuir}

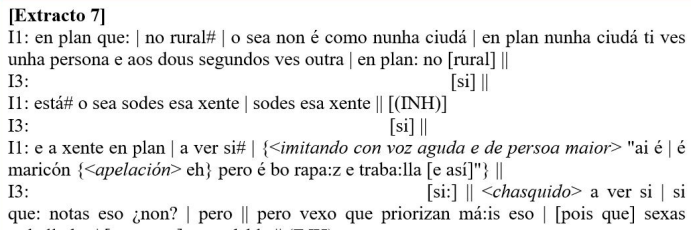

Neste anaco de conversa, o I1 e o I3, que se identifican como sendo de adscrición rural, discuten sobre as redes socio-xeográficas en que están inseridos en relación ao tratamento da sexualidade. A causa disto foi o interese suscitado polo I 2 sobre a relación entre o ámbito rural e a sexualidade, logo de falar das imaxes de diferentes "tipos" de homes non heterosexuais. Os dous falantes deste extracto non dubidaron desde o primeiro momento en se identificar e en tomar como referente a Rodrigo Cuevas, precisamente por causa da súa particular relación co agro tanto a nivel de representación como a nivel persoal ou biográfico. 
Daquela curiosidade do I2, derivan estas descricións dos comportamentos lingüísticos e ideolóxicos das persoas do rural a respecto da sexualidade. E unha primeira consideración debe ser feita ao recoñecermos con Joseph (2004: 117) que a nacional non é a identidade pola que as persoas máis sacrificarían ("regional and local identities matter..."): o I1 (e, en menor medida, o I3) mantén as características dialectais do seu galego, mesmo tendo estudado en Santiago de Compostela durante anos. Este feito podería ser visto como un elemento de resistencia aos procesos, moitas veces ligados ao mundo gay, de homoxeneización cultural paralela a unha maior interconexión e mobilidade, no seo da superdiversidade de que xa falamos (Johnstone 2008: 152; Blommaert 2010).

Un dos aspectos que máis chama a atención do excerto é a inclusión da persoa que fala no grupo a que pertence a través dunha forma verbal P5, acompañada dun demostrativo deíctico: "sodes esa xente, sodes esa xente". Recoñécese o lugar en que se vive como unha comunidade de práctica e, fronte á posibilidade de se posicionar mediante a alusión a certos circuítos de ocio ou de comunicación homosexuais, decide marcar a súa rede social sen xebrala con base na identidade sexual. Cremos, neste sentido, que Blommaert acerta cando sinala que "[s]pace can be filled with all kinds of social, cultural, epistemic, and affective attributes. It then becomes 'place', a particular space on which senses of belonging, property rights, and authority can be projected" (apud Milani 2013: 206-207).

As características prosódicas con que emula o enunciado idealmente proferido por unha señora de idade ou a concepción de prioridades ou atributos que fan con que a sexualidade non totalice a concepción social dun individuo e o seu tratamento na ecoloxía comunicativa son outros trazos salientábeis no tocante á

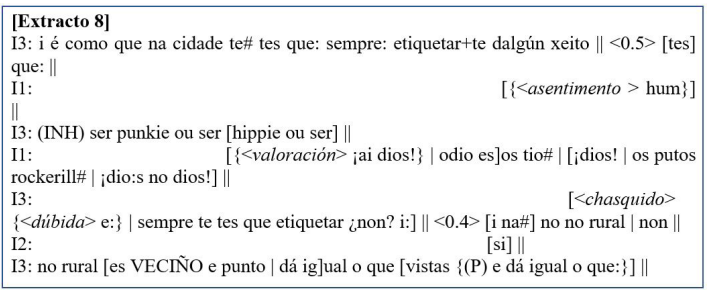

indexicalidade, en referencia á xestión discursiva do coñecemento nas ruralidades queer.

De novo, é usada unha segunda persoa verbal ("tes", "es"...) que marca a presenza de ligazón dos falantes con esas redes densas e múltiples que vertebran o ámbito rural. A partir do fío temático da "etiquetaxe" necesaria, asociada ao mundo urbano, defenderemos unha concepción agrocuir ${ }^{10}$ da sexualidade.

O I3 marca unha certa distinción co I2, de adscrición urbana, ao tempo que tece co I1, do punto de vista posicional, unha identidade como "veciño", que emerxe no discurso após varias consideracións e historias persoais sobre o binomio rural-sexualidade. A necesidade de marcar unha diferenza, por exemplo a través da vestimenta ou da estética en xeral (“dá igual o que vistas e dá igual o que..."), marcaría un corte semiótico nesta cuestión interseccional. Fronte á liberalización, comercialización e turistificación da cultura homosexual, aparece ante nós a alternativa "agrocuir" ou agrosexual, que loita contra o proceso polo que "la geografía homosexual se ramifica hacia los grandes centros urbanos, de los cuales algunas ciudades tienen una bien ganada fama de ser particularmente gay" (Pollack 1987: 91).

Para a correcta comprensión desta cuestión é preciso botar man da noción de "metronormatividade" que antes citamos e da de "homonormatividade" que diversos autores de distintas áreas disciplinares, especialmente da xeografía da sexualidade, teñen teorizado. Nomeadamente, é indispensábel valorar a achega de Lisa Duggan (2003), Garvin Brown (2009, 2012) e, no caso galego, de Xosé M. Santos (1998). Este último asegura que ...a transmisión dunha imaxe de liberdade na que
se ofrece unha cidade na que as persoas poden ex-
presar abertamente as súas preferencias sexuais
e atopar apoio e amizades noutra xente que com-
parte unha causa común, resulta un atractivo de-
masiado forte para quen vive no ambiente repre-
sivo da "periferia". Deste xeito, o fenómeno da
emigración selectiva, que afecta de maneira bas-
tante importante ós gais e lesbianas, acada unha
importancia maior. Madrid pasa a ser o obxectivo
central dos desexos de xente nova na procura do
anonimato da gran cidade e do proxecto común
da homosexualidade. (1998: 26-27)

10 Tomamos o termo do Colectivo Agrocuir da Ulloa, organizador do Festival Agrocuir, que en agosto de 2018 celebrou a súa quinta edición: https://festivalagrocuir.wordpress.com/about/ [consultado: 12/05/2019]. 
[Extracto 9]

I1: a ver claro [que no ru\# en plan: ;claro! | si vas en plan a un] sitio en plan superpequeno e tal estarán acostumbrados en plan porque ven na televisión que hai maricóns deses e así [e ao mellor en plan]

I3: $\quad$ [pero todo non se pode pedir | (risas)] || [TA MÉ:N | están\# están coa tele

I1: [o\# o\# o\# ;claro! | (INH)] e ó mellor o fillo de algún sále+lle maricón e din "\{<apelación $>$ ai $\}$ o fillo deste é mari[cón non sei que] tal" $\|($ INH)

\{<apelación $>$ ai\} o fillo deste e mari con non sei que tal" $\|$ (INH)
$\qquad\{<$ asentimento $>$ hum $\}] \|$

I1: pero en plan | que veña en plan | un puto maricón de outro lado: || e di "\{<apelación $>$ ¡ai\} mimá! que é mari[cón] tal | e é bo rapaz e así e traballa | [\{<apelación> ¡ai\} mim]á! e non: non quere solo estar a: [en plan de vago] e así" ||

No seo de todo este debate faise inevitábel destacar o forte papel que, na opinión dos interlocutores, xogan os referentes da "cultura homosexual" na televisión. As imaxes de Jorge Javier Vázquez e o contraste que procuramos crear coas da outra figura derivaron na valoración das diferentes imaxes que se dan sobre a homosexualidade masculina nos grandes medios. En diferentes momentos conversacionais acusan a este tipo de figuras, de clase alta, de transmitir estereotipos e de asumir os privilexios que o sistema capitalista lles brindou. Este treito parece ser un bo exemplo da homonormatividade que tan ben moldea Brown:

As social and political attitudes towards lesbians and gay men have become more tolerant, mainstream media portrayals of gay people have proliferated and an increasing number of major corporations have marketed their products and services towards lesbian and gay consumers. (...) In contrast to the theorisations of Duggan and Richardson, Nast has located these social and economic changes firmly within the reconfigured racist, patriarchal privilege of " "normative' gay white male masculinities" (2002, page 878). (Brown 2009: 1499)

O mecanismo discursivo autorizador da homosexualidade responde ás imaxes que a televisión ofrece sobre os suxeitos en cuestión. O I1, a este respecto, banaliza a identidade gay mediante un proceso de especificación formal que non leva parella unha mesma especificación do contido: "porque ven na televisión que hai maricóns deses e así". Con ese modificador, desdebúxase o carácter prioritario da condición sexual na identidade local de que as persoas da aldea fan parte en tanto participan das redes sociais. A importancia do lugar desde o que se fala e da interrelación dos individuos co resto de participantes dos circuítos comunicativos é reiterada en diversos momentos: "o fillo deste é maricón", "pero (...) que veña (...) un maricón doutro lado" etc. Unha cultura do traballo e da conversa, da comunidade en termos laborais e lingüísticos, moldea a concepción dos individuos con sexualidades disidentes, con máis relevancia das identidades cronotópicas (Blommaert e De Fina 2016) - coa cidade contemporánea como espazo-tempo ao lado da aldea, en que diferentes frames demandan distintas performances-do que sexuais: "é bo rapaz e traballa, non quere só estar de vago". Os atributos definitorios empregados poñen de manifesto dúas cuestións: a existencia dun tabú social sobre a sexualidade, como indican os propios falantes en enunciados anteriores recoñécese que unha persoa é "maricón" mais non se verbaliza como tal en sociedade-, e unha aceptación implícita con base na distinción paralela á integración en termos de "traballo" (quer no sentido estrito da forza laboral, quer no sentido máis abstracto de labor comunicativo e interaccional). Faltan as etiquetas no nivel conceptual, mais precisamente por isto se dá unha desestabilización da ilexitimación, en termos de Bucholtz e Hall (2005), unha vez que a identidade sexual non é censurada. Dito doutra maneira, a ausencia de palabras para designar determinadas identidades sexuais é un feito discursivamente interesante debido ás particularidades da identificación homosexual: a esencia gay sería a súa dimensión verbaliza$\mathrm{da}$-es gay porque te enuncias e te enuncian como tal- e, neste caso, ese proceso ritualizado de percepción (e, por tanto, de aceptación e rexeitamento) é, en certa forma, modificado ou violado.

Podería argumentarse que estes espazos -rurais e até periurbanos- non cuestionan o "homonormative turn" de que fala Lucy Jones (2018: 56) mediante a crítica recollida de Valentine, entendida esta noción como "a process of institutionalisation, leading to the expectation that gay and lesbian people will 'conduct themselves as implicitly «straight» members of society"'. Porén, a identidade veciñal, aínda que non fique fóra das imposicións heteropatriarcais macroestruturais, é combativa coas exixencias capitalistas de homoxeneización, crecente individualismo e política identitaria centrífuga. Os informantes chegan a cuestionar a inclusión supralocal das súas identidades sexuais e locais desde a súa posición socioeconómica:

\footnotetext{
[Extracto 10]

I3: $\{$ (PP) si $\}$ pero porque unha CLASE social alta e porque:: $\|<0.8>$ pero despois a: nó non sei se nos aceptarían tan ben $\|$ es $[$ a xen]te $\mid$ ¿entendes $\mid$ o que quero dicir? $\|<1.4>$ I1:

I3: [pa min a] min non me representa claro \{<dibida $>$ e:\} obviamente | ino! || I1: [xa] ||
}

No campo social que os diferentes suxeitos falantes comparten no marco da súa ecoloxía rural, existen violacións e reformulacións dos habitus dos diferentes axentes, todos eles so diferentes formas de violencia simbólica, que poden ser respondidas desde diferentes 
posicións identitarias que se interseccionan e relacionan en diferentes espazos. Entón, tal concepción agrocuir tensa as cordas da relacionalidade entre os polos da adecuación e da distinción. As súas consecuencias emancipatorias pasan por unha naturalización desesencializada das diferentes sexualidades no seo de redes densas que, no entanto, non abandonan ideoloxías esencialistas sobre a a sexualidade: o fillo dunha veciña "sáelle maricón".

É particularmente relevante a presenza positivamente valorada de procesos e axentes de representación, como poderían ser os protagonistas das imaxes mostradas. Para que opere a lexitimación sobre un colectivo agredido, parecen necesarios individuos e accións que, desde posicións de poder e visibilización, normalicen a diversidade de condicións sexo-afectivas. Non obstante, isto non sempre satisfai: "a min non me representa". O I3 chega a pór en causa que nós - "which pressuposes agreement with the reader and the authority to speak for others" (Benwell e Stokoe 2006: 115)-, un colectivo que inclúe os seus interlocutores, sexan aceptados neses circuítos de representación, entre outras razóns pola cuestión de clase, presente en case todo momento na súa discusión sobre a sexualidade. De todas as maneiras, esta idea é expresada con sutile$\mathrm{za}$, tendo en conta a diversidade de traxectorias biográficas e de hábitats de procedencia: "pero despois a nós non sei se nos aceptarían tan ben, esa xente, ¿entendes o que quero dicir?". Comeza cunha conxunción adversativa que marca unha diferenza no relato, continúa cun adverbio temporal que procura crear unha distancia secuencial, enfatiza o colectivo afectado pola proposición, engade unha estrutura condicional, coloca un adverbio para atenuar o grao de afección, sinala o axente en cuestión cunha especificación demostrativa ("esa xente") e remata cunha interpelación atenuante que busca a corroboración dos interlocutores. E todo isto para afirmar que a súa proposición é suficientemente semellante á do resto, mediante unha avaliación relacional das posicións discursivas dos outros empregando estratexias pragmáticas. Úneos unha identidade grupal que, desde a pregunta inicial do I1 en que usa de maneira chocante na interacción o termo "maricón", está suxeita a unha constante adecuación: enténdena como común a todos eles mais, se abrirmos o foco de análise e formos cara a outros vectores identitarios, experiencias de vida e ideoloxías, ilexitímana constante e orixinalmente.

\section{Conclusións}

Ao longo desta incursión tentamos estudar algúns dos fenómenos envolvidos na relación entre discurso e sexualidade a través da análise dun pequeno corpus de perto de sesenta minutos de gravación. Da observación e intuición persoal dos últimos anos tiramos certas ideas e concepcións sobre este asunto que nos encamiñaron a facer unha aproximación como a que aquí se presenta, tanto na temática como na metodoloxía. Unha vez deseñado, compilado e sistematizado o corpus, propuxémonos lelo criticamente á luz de distintos prismas teóricos: a ACD, os estudos de xénero e sexualidade e as teorías da identidade. Polo tanto, na análise resaltamos algúns aspectos que nos resultaron fulcrais nestas liñas: as etiquetas identitarias, a dimensión lingüística da "saída do armario" e o relacionamento entre a identidade sexual e as características do hábitat ou lugar de procedencia. En conclusión, tres ideas fundamentais subxacen a estas páxinas.

Primeiro, nos discursos contemporáneos que están a circular hoxe na Galiza existen mecanismos e estratexias de subversión sexual presentes na fala. A reapropiación de termos e expresións ofensivas para colectivos lidos como diferentes e socialmente discriminados está en andamento. En concreto, o caso de "maricón" é rechamante por esta razón: a linguaxe de odio pode ser, tamén en galego, parodiada de maneira restitutiva. Ademais, o uso de etiquetas identitarias non se perde, no noso estudo de caso, en exixencias da contemporaneidade anglófona, senón que se entende como relevante para a relación que gardan entre si os diferentes axentes dunha comunidade comunicativa.

Segundo, en paralelo ás etiquetas, a saída do armario é necesaria como máis unha medida de normalización e visibilización. Porén, as posibilidades performativas da acción identitaria na comunicación diaria ábrense para o cuestionamento de identidades estancas subsumidas a aspectos biolóxicos. O xénero e a súa diversidade intrínseca facilitan a indefinición, mais sen desbotar a verbalización da condición identitaria dos suxeitos en determinadas ocasións en que esta aínda é necesaria. En definitiva, os elementos lingüísticos da sexualidade poden ser usados para colaborar coa súa comprensión abranxente e respectuosa. Non hai unha única e unívoca forma de visibilización, e esta sempre terá de ser contextualizada. 
Finalmente, no actual discurso non heterosexual deste país, como este pequeno estudo tentou mostrar servindo de exemplo, existe consciencia de se estar a producir un proceso de homoxeneización cultural (e, en consecuencia, lingüística) e de absorción das sexualidades periféricas por parte de modelos de conduta, organización e relación co medio natural típicas da heterosexualidade normativa neoliberal e urbana. Da mesma maneira, para as persoas con menos recursos no actual estadio do sistema mundial capitalista, o acceso libre e dialogante con aquilo que non encaixa en tal sistema está mediatizado polos grandes medios de consumo, comunicación e entretemento. As implicacións ideolóxicas desta tendencia poden ser combatidas mediante unha maior proximidade entre o rural e a diversidade sexual, entre o respecto pola terra e pola identidade. Tal traballo, cremos, debe focarse no afianzamento do espírito comunitario, especialmente no seu esquelete conversacional, que quixemos resaltar neste pequeno e primeiro - esperemos que de moitos máis e máis amplos- contributo académico.

\section{Referencias bibliográficas}

Anónimo (2016): "Luchar contra la homofobia desde el aula", El País (Madrid) 18/05/2016.

Austin, John L. (2004 [1962]): Cómo hacer cosas con palabras: palabras y acciones. Compilado por J. O. Urmson. Barcelona: Paidós.

Barrett, Rusty (1997): "The «Homo-genius» Speech Community”, en A. Livia e K. Hall (eds.), Queerly Phrased. Nova York: Oxford University Press, pp. 181-201.

Baker, Kelly (2011): "Conceptualizing Rural Queerness and Its Challenges for the Politics of Visibility", Platforum 12, pp. 38-56.

Basanta, Noemi (2014): “(Re)presentar as identidades: a construción discursiva do xénero na conversación”, Estudos de Lingüística Galega 6, pp. 29-51, http://www.usc.es/revistas/index.php/elg/article/ view/1744/2002.

(2017): "Fainos cambiar a situación e a propia evolución da vida, non?: identidade e performance en narrativas relacionalmente mediadas", en X. L. Regueira e E. Fernández Rei (eds.), Estudos sobre o cambio lingüistico no galego actual. Santiago de Compostela: Consello da Cultura Galega, pp. 157-186.

Bengoechea Bartolomé, Mercedes (2015): Lengua y género. Madrid: Síntesis.

Benwell, Bethan e Elizabeth Stokoe (2006): Discourse and Identity. Edimburgo: Edinburgh University Press.

Blommaert, Jan (2010): The Sociolinguistics of Globalization. Cambridge: Cambridge University Press.

Blommaert, Jan e Ben Rampton (2011): "Language and Superdiversity", Diversities 13/2, pp. 1-21.

Blommaert, Jan e Anna de Fina (2016): "Chronotopic Identities. On the Timespace Organization of Who We Are", en A. de Fina, I. Didem e J. Wegner (eds.), Diversity and Superdiversity: Sociocultural Linguistic Perspectives. Washington DC: Georgetown University Press, pp. 1-15.

Borba, Rodrigo (2015): "Linguística Queer: uma perspectiva pós-identitária para os estudos da linguagem", Revista Entrelinhas 9/1, pp. 91-107, http://revistas.unisinos.br/index.php/entrelinhas/article/view/10378.

Bourdieu, Pierre (1994): Language and symbolic power. Cambridge: Harvard University Press.

(2015): La dominación masculina. Barcelona: Anagrama.

Brown, Garvin (2009): "Thinking beyond homonormativity: performative explorations of diverse gay economies", Environment and Planning 41, pp. 1496-1510, https://journals.sagepub.com/doi/10.1068/a4162.

(2012): "Homonormativity: A Metropolitan Concept that Denigrates «Ordinary» Gay Lives", Journal of Homosexuality 59, pp. 1065-1072, https://www.tandfonline.com/doi/full/10.1080/00918369.2012.699851.

Bucholtz, Mary (2003): "Sociolinguistic nostalgia and the authetication of identity", Journal of Sociolinguistics 7(3), pp. 338-416, https://onlinelibrary.wiley.com/doi/10.1111/1467-9481.00232.

(2017): "The Feminist Foundations of Language, Gender, and Sexuality Research", en S. Ehrlich, M. Meyerhoff e J. Holmes (eds.), The Handbook of Language, Gender and Sexuality. Oxford: Wiley Blackwell, pp. 23-47.

Bucholtz, Mary e Kira Hall (2005): "Identity and interaction: a sociocultural linguistic approach", Discourse Studies 7/4-5, pp. 585-614, https://journals.sagepub.com/doi/pdf/10.1177/1461445605054407.

Butler, Judith (1993): Bodies that Matter. On the Discursive Limits of "Sex". Nova York; Londres: Routledge.

(2004 [1997]): Lenguaje, poder e identidad. Madrid: Síntesis.

(2010 [1990]): El género en disputa: el feminismo y la subversión de la identidad. Barcelona: Paidós Ibérica. 
Calsamiglia, Helena e Amparo Tusón (2002): Las cosas del decir: manual de análisis del discurso. Barcelona: Ariel.

Cameron, Deborah (2005): “Language, Gender and Sexuality: Current Issues and New Directions", Applied Linguistics 26/4, pp. 482-502, https://academic.oup.com/applij/article/26/4/482/145308.

Cameron, Deborah e Don Kulick (2003): Language and sexuality. Cambridge: Cambrige University Press.

Connell, Raewyn W. (1998): Gender and Power. Society, the Person and Sexual Politics. Cambridge: Polity Press.

CORILGA = Xosé Luís Regueira Fernández (dir.) (2012-): Corpus Oral Informatizado da Lingua Galega. Santiago de Compostela: Instituto da Lingua Galega, http://ilg.usc.es/corilga/ [consultado 08/06/2019].

Duggan, Lisa (2003): The Twilight of Equality?: Neoliberalism, Cultural Politics, and the Attack on Democracy. Boston: Beacon Press.

Eckert, Penelope e Sally McConnell-Ginet (1992): "Think practically and look locally: Language and gender as community-based practice", Annual Review of Anthropology 21, pp. 461-490, https://www. annualreviews.org/doi/abs/10.1146/annurev.an.21.100192.002333.

Ehrlich, Susan; Miriam Meyerhoff e Janet Holmes (eds.) (2017): The Handbook of Language, Gender and Sexuality. Oxford: Wiley Blackwell.

ELAN - Versión 5.2 (2018). Nijmegen: Max Planck Institute for Psycholinguistics. Dispoñíbel en: https:// tla.mpi.nl/tools/tla-tools/elan/.

Erickson, Frederik (2004): Talk and Social Theory. Cambridge: Polity.

Fairclough, Norman (1995): Critical Discourse Analysis: The Critical Study of Language. Londres: Longman.

Foucault, Michel (2006 [1976]): Historia de la sexualidad. México: Siglo XXI.

Giddens, Anthony (1998): La transformación de la intimidad. Sexualidad, amor y erotismo en las sociedades modernas. Madrid: Cátedra.

Greco, Luca (2012): "Production, circulation and deconstruction of gender norms in LGBTQ speech practices", Discourse Studies 14/5, pp. 567-585, https://journals.sagepub.com/doi/full/10.1177/1461445612452229.

(2015): "Analyse de conversation, anthropologie linguistique et analyse critique du discours: historiciser les débats, intégrer les approches", Langage \& Société 153 ( $3^{\circ}$ trimestre), pp. 135-153, https:// www.cairn.info/revue-langage-et-societe-2015-3-page-135.htm.

(2016): "Définir le genre et la parenté en contexte LGBTQ: la définition comme laboratoire catégoriel et comme performance", Langages 204/4, pp. 139-158, https:/www.cairn.info/revue-langages2016-4-page-139.htm.

Halberstam, Jack (2005): In a Queer Time and Place. Transgender Bodies, Subcultural Lives. Nova York; Londres: New York University Press.

Hall, Stuart (2011): “The neoliberal revolution”, Cultural Studies 25/6, pp. 705-728.

Johnstone, Barbara (2008): Discourse Analysis. Oxford: Blackwell.

Jones, Lucy (2018): “«I'm not proud, I'm just gay»: lesbian and gay youths' discursive negotiation of otherness", Journal of Sociolinguistics 22/1, pp. 55-76, https://onlinelibrary.wiley.com/doi/10.1111/josl.12271.

Joseph, John E. (2004): Language and Identity. National, Ethnic, Religious. Londres: Palgrave Macmillan.

Labov, William (1983 [1972]): Modelos sociolingüisticos. Madrid: Cátedra.

Lakoff, Robin (1975): Language and Women's Place. Nova York: Harper \& Row.

Leap, William (1996): Word's Out: Gay Men's English. Minneapolis: University of Minnesota Press.

Levon, Erez (2015): “The Ideal Gay Man'. Narrating Masculinity and National Identity in Israel”, en T. M. Milani (ed.), Language and Masculinities. Performances, Intersections, Dislocations. Nova York: Routledge, pp. 133-155.

Levon, Erez e Ronald Beline Mendes (2016): Language, Sexuality and Power. Nova York: Oxford University Press.

Liang, A. C. (1997): "The Creation of Coherence in Coming-Out Stories", en A. Livia e K. Hall (eds.), Queerly Phrased. Nova York: Oxford University Press, pp. 287-309.

Livia, Anna e Kira Hall (eds.) (1997): Queerly Phrased. Nova York: Oxford University Press.

Milani, Tommaso M. (2013): "Expanding the Queer Linguistic scene. Multimodality, space and sexuality at a South African university", Journal of Language and Sexuality 2/2, pp. 206-234, https://benjamins. com/catalog/jls.2.2.02mil.

Moore, Emma (2010): “Communities of Practice and Peripherality", en C. Llamas e D. Watt (eds.), Language and Identities. Edimburgo: Edinburgh University Press, pp. 123-133. 
Mondada, Lorenza e Florence Oloff (2015): “«Hetero oder homo?» La performance d'un coming out hétérosexuel à la radio", Langage \& Société 152 (2 semestre 2015), pp. 17-40, https://www.cairn.info/ revue-langage-et-societe-2015-2-page-17.htm.

Payrató, Lluís (2003): Pragmàtica, discurs i llengua oral. Introducció a l'anàlisi funcional de textos. Barcelona: Editorial UOC.

Pollak, Michael (1987): “La homosexualidad masculina ¿o la felicidad en el ghetto?”, en P. Àries, A. Béjin, M. Foucault et alii, Sexualidades Occidentales. Buenos Aires: Paidós, pp. 71-102.

Queen, Robin (2017): "Language and Sexual Identities", en S. Ehrlich, M. Meyerhoff e J. Holmes (eds.), The Handbook of Language, Gender and Sexuality. Oxford: Wiley Blackwell, pp. 203-219.

Santos, Xosé M. (1998): "O espacio da homosexualidade en Galicia”, Fluxos 1, pp. 23-34.

Santos, Boaventura de Sousa (2005): "A crítica da governação neoliberal: O Fórum Social Mundial como política e legalidade cosmopolita subalterna”, Revista Crítica de Ciências Sociais 72, pp. 7-44, https:// journals.openedition.org/rces/979.

Schweighofer, Katherine (2016): "Rethinking the Closet. Queer Life in Rural Geographies", en M. L. Gray, C. R. Johnson e B. J. Gilley (eds.), Queering the Countryside. New Frontiers in Rural Queer Studies. Nova York; Londres: New York University Press, pp. 223-243.

Sedgwick, Eve Kosofsky (2003 [1990]): Epistemologia do Armário. Coimbra: Angelus Novus.

Souza, Luís Antônio Francisco de (2010): "Dilemas e hesitações da modernidade tardia e a emergência da sociedade de controle", Mediações 15/1, pp. 78-99, http://www.uel.br/revistas/uel/index.php/ mediacoes/article/view/8227.

Tannen, Deborah (1991): You Just Don't Understand. Londres: Virago.

Valcárcel Riveiro, Carlos (1998): "Lingua, comunidade e sexualidade: a prensa homosexual na Iberorromania", Fluxos 1, pp. 35-50.

van Dijk, Teun A. (1995a): “Aims of Critical Discourse Analysis”, Japanese Discourse 1, pp. 17-27. (1995b): "Discouse Analysis as Ideology Analysis", en C. Schäffner e A. Wenden (eds.), Language and Peace. Aldershot: Dartmouth Publishing, pp. 17-33.

(2015): "Critical Discourse Analysis", en D. Tannen, H. E. Hamilton e D. Schiffrin (eds.), The Handbook of Discourse Analysis. Oxford: Wiley Blackwell, pp. 466-485. 